\title{
Position of the American Dietetic Association: Food and Nutrition Professionals Can Implement Practices to Conserve Natural Resources and Support Ecological Sustainability
}

\section{ABSTRACT}

It is the position of the American Dietetic Association to encourage environmentally responsible practices that conserve natural resources, minimize the quantity of waste generated, and support the ecological sustainability of the food system - the process of food production, transformation, distribution, access, and consumption. Registered dietitians and dietetic technicians, registered, play various roles in the food system and work in settings where efforts to conserve can have significant effects. Natural resources that provide the foundation for the food system include biodiversity, soil, land, energy, water, and air. A food system that degrades or depletes its resource base is not sustainable. Making wise food purchases and food management decisions entails understanding the external costs of food production and foodservice and how these external costs affect food system sustainability. This position paper provides information, specific action-oriented strategies, and resources to guide registered dietitians and dietetic technicians, registered, in food decision making and professional practice. Food and nutrition professionals also can participate in policy making at the local, state, and national levels, and can support policies that encourage the development of local sustainable food systems. Our actions today have global consequences. Conserving and protecting resources will contribute to the sustainability of the global food system now and in the future.

$J$ Am Diet Assoc. 2007;107:

1033-1043.

0002-8223/07/ 10706-0025\$32.00/0

doi: 10.1016/j.jada.2007.04.018

\section{POSITION STATEMENT}

It is the position of the American Dietetic Association to encourage environmentally responsible practices that conserve natural resources, minimize the quantity of waste generated, and support the ecological sustainability of the food system - the process of food production, transformation, distribution, access, and consumption.

embers of the American Dietetic Association (ADA) work in settings where efforts to conserve natural resources, minimize waste, and support the ecological sustainability of the food system can have significant effects. The ADA is committed to research, policy, and programs designed to conserve natural resources and promote ecological sustainability. The ADA also encourages members to understand the global implications of our actions. Competition for scarce resources such as clean water, energy, and arable land will intensify in the face of global warming and an expanding global population. Learning what we can do now to conserve resources and acting on that information is critical for the future sustainability of the food system.

The first section of this position paper describes ecological sustainability in the context of the food system and highlights the role of registered dietitians (RDs) and dietetic technicians, registered (DTRs). Section two suggests ways that RDs and DTRs can take actions in their workplaces that directly reduce energy consumption, protect water and air quality, and minimize and effectively manage solid and hazardous waste. Section three describes the environmental issues related to food production in the
United States, how food and nutrition professionals can support sustainable agriculture through food guidance, and ways to help build community food systems that conserve natural resources. The position concludes by providing some global perspective.

\section{THE FOOD SYSTEM AND ECOLOGICAL SUSTAINABILITY}

Sobal and colleagues (1) describe the food and nutrition system as the transformation of raw materials into foods and then nutrients into health outcomes, within biophysical and sociocultural contexts. The sectors of the food system include: 1) production, 2) transformation (processing, packaging, labeling), 3) distribution (wholesaling, storage, transportation), 4) access (retailing, institutional foodservice, emergency food programs), and 5) consumption (preparation, health outcomes). A pool of human and natural resources serves as the foundation of the food system, and other factors such as technology, policy, economics, sociocultural trends, research, and education all affect how the system functions.

Sustainability means capable of being maintained over the long term (2), and meeting the needs of the present without compromising the ability of future generations to meet their needs (3). To maintain the food system, the raw materials (inputs) for foods and natural resources used for food transformation and distribution must be conserved, not depleted or degraded (4). A sustainable diet is composed of foods that contribute to human health and also encourage the sustainability of food production (5) (Figure 1).

Food and nutrition professionals 


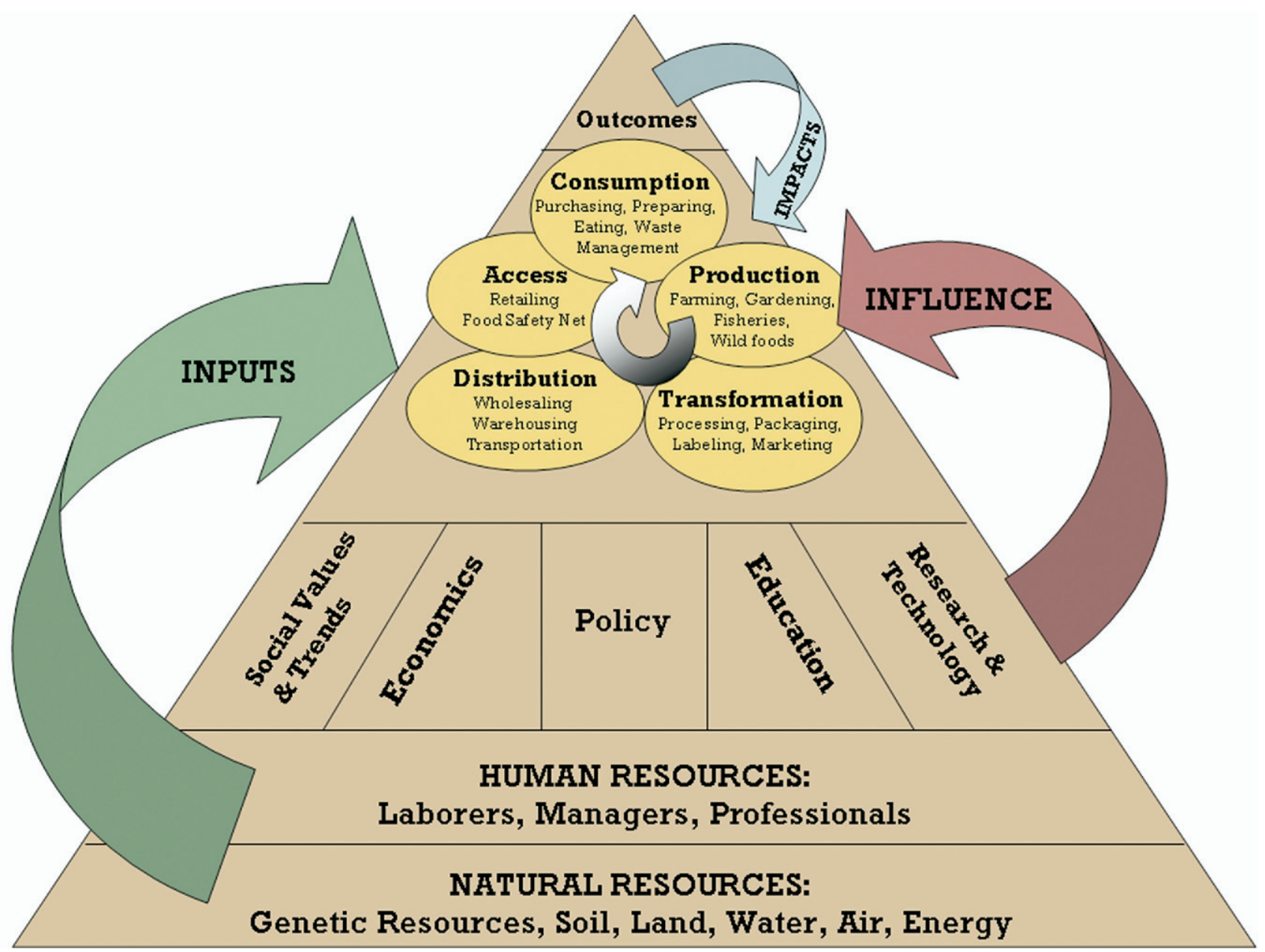

Figure 1. Sustainable Food System Model. (Reprinted with permission from: American Dietetic Association Sustainable Food System Task Force. Healthy Land, Healthy People: Building a Better Understanding of Sustainable Food Systems for Food and Nutrition Professionals. Chicago, IL: American Dietetic Association; 2007.)

have opportunities to influence natural resource conservation, solid waste minimization, and ecological sustainability through the variety of roles they serve in the food system. For example, RDs and DTRs who practice clinical nutrition have the potential to influence patient food choices and are, therefore, key players in the consumption sector of the food system. Food and nutrition managers have an important role in the food distribution and access sector of the food systemprocuring, preparing, and serving food in large quantities.

\section{DIRECT CONSERVATION OF RESOURCES Energy}

The US food system is highly dependent on energy for the production, processing, packaging, and distribu- tion of food. The cost and availability of oil either directly or indirectly affects all food system inputs, including other forms of energy. The United States is a net importer of oil, having reached its maximum oil production in 1970 (6). The Energy Information Administration predicts that the commercial sector (which includes commercial and on-site foodservices) will increase energy consumption from petroleum from 33.5 quadrillion Btu (British thermal units) in 1990 to 50 quadrillion Btu in 2030 (6). The increases in crude oil prices since 2000 are a result of global demand and a decreasing supply of readily accessible oil (6).

Foodservice operations are intensive users of both natural gas and electricity. On average, foodservice operations consume 250,000 Btu per square foot, more than 2.5 times the energy consumed by other activities in a given building (7). Energy consumption for the foodservice sector has increased 18\% during the period 1990 to 2004 (6). Direct energy consumption for foodservice operations averages $30 \%$ for cooking, $19 \%$ for refrigeration, and $10 \%$ for sanitation (7). Increased energy consumption by retail and on-site food production can be anticipated because over $50 \%$ of the US food dollar is spent on meals prepared away from home $(8,9)$. Food and nutrition professionals have an additional incentive to conserve because they can expect higher food prices as well as higher utility bills as a result of increasing energy costs.

The federal government has established several energy conservation initiatives, such as Energy Star, which 
describes the national energy efficiency standards for residential and commercial equipment (10). Qualifying foodservice equipment, such as steamers, refrigerators, and gas-powered fryers, must reduce energy consumption by $25 \%$ to $60 \%$ to receive the Energy Star rating. Rebates or tax credits may be available to facilities switching to Energy Star-rated equipment (11). Practicing energy conservation can result in $\$ 20$ in new revenues for every dollar saved or a 1-cent increase in earnings per share for nonprofit and for-profit health care facilities, respectively (12).

New food production equipment combines existing preparation methods with more energy-efficient design. Microwave ovens have a cooking efficiency (the fraction of energy that heats food during the cooking cycle) of $57 \%$, compared with $17 \%$ and $8.7 \%$ cooking efficiency for electric and gas convection ovens, respectively (13). Electricity-powered induction cookers heat only at the cooking surface, consuming less energy and cooking faster than gas equipment. Supercookers combine convection, microwave, and impingement methods in a single piece of equipment. The supercooker prepares food much faster than conventional methods while consuming less energy (14). Water-cooled icemakers use less electricity than aircooled models. They also disperse less heat into the kitchen, thus decreasing air conditioning loads. The compressed nugget ice produced by these icemakers uses less energy and water than cube icemakers (15). Some commercial equipment, such as gas cooking equipment, gas heaters, and electric heat pumps, have been excluded from upgraded standards because of limited market demand for such products and lack of adequate data to develop standards (10). Energy Management Systems establish the lowest possible demand load and then maintain it by cycling all on-and-off equipment by controlling hours of usage resulting in a level load demand (16). Energy efficiency can be included in equipment specifications.

Alternative energy sources such as solar and wind power may reduce oil dependency as the technologies become more cost effective. Wholebuilding design approaches use alternative energy sources, integrated energy management systems, and site placement that minimize environmental impact of new construction. For example, new retail space construction in Silverthorne, CO, combined natural light and air flow patterns with other technology, resulting in energy cost savings of $62 \%$ over conventional designs (17).

\begin{tabular}{l}
\hline Learning what we \\
can do now to \\
conserve resources \\
and acting on that \\
information is \\
critical for the future \\
sustainability of the \\
food system.
\end{tabular}

To conserve energy, food and nutrition professionals must understand consumption patterns within their facilities. Energy audits (inventory of all energy-using equipment) and energy tracking (recording time and duration of energy use) are two methods of identifying all power-consuming equipment and determining the amount of energy the equipment consumes. Peak demand times as well as conservation opportunities are identified through the process. Food and nutrition professionals can use the energy-tracking methodology proposed by Mason and colleagues (18). Another option available is the Environmental Protection Agency's (EPA's) energy performance rating system that tracks a facility's energy consumption over time, providing management with benchmarking data from similar facilities nationwide (12).

Numerous opportunities exist for food and nutrition professionals to conserve energy-using existing food production equipment. Oven and broiler preheating times should be minimized and full loads cooked whenever possible. Timers minimize opening the door to check food. Oven seals should be checked periodically for wear or food debris, which can cause heat to escape (13). For small production facilities, stovetop food preparation is more efficient when cookware bottoms are not warped, cookware is the appropriate size for the burner, and lids are used. Turn- ing an electric stovetop element off several minutes before the allotted cooking time uses residual heat to finish cooking while saving energy. All food production facilities should run equipment with full loads whenever possible, turn off equipment when not in use, and implement equipment cleaning and maintenance schedules (19). Efficient energy use is important because electricity generation from power plants creates wastes in the form of carbon dioxide, particulates, and water that must be cooled before release into the environment. Alternative power sources should be considered; however, the most efficient energy source will vary from region to region. Practitioners should consider all factors when allocating resources (20).

\section{Water}

Water is an essential natural resource that must be protected from contamination. The commercial sector, which includes health care, public institutions, and restaurants, consumes 900 million gallons of water per day-1\% of total freshwater use (21). Food production water use ranges from 1.5 gallons/meal for school lunch to 2.0 gallons/meal for full-service restaurants or cafeterias (16). Population shifts from urban to suburban areas results in conversion of former agricultural land to residential/commercial properties. This trend has the effect of increasing the delivery range of municipal water systems and increasing cost for fresh water delivery and wastewater treatment.

The Clean Water Act (1970) and the Safe Water Drinking Act (1974) are the two major pieces of legislation concerning the US water supply. Americans have historically paid less for water than the cost of treatment and delivery. The average cost of tap water is $\$ 1.20$ per 1,000 gallons (21). Water conservation has several potential benefits, including reducing polluted runoff, decreased demand for reservoir construction with associated habitat alterations, and wetlands protection, in addition to reducing operating costs for facilities (20). The ADA's position on food and water safety describes water safety and quality in greater detail (22).

Programs such as Water Alliance 
for Voluntary Efficiency, WaterWiser, WaterSense, and WATERGY provide resources such as educational programs, conservation technology, and marketing assistance to participating organizations (23-26). Sanitation equipment now includes water-saving and energy-saving features. Hightemperature, final-rinse spray nozzles have been developed for dish machines to use significantly less water than conventional spray nozzles. Manufacturers are offering insulated water tanks and sensors mounted on water spray nozzles as methods to reduce energy and water consumption (27). Technology such as hot water recirculation-loop pumps have the potential to reduce water and energy consumption in school cafeterias (28). Hands-free sinks reduce water consumption while encouraging frequent hand washing (29).

Food and nutrition professionals can decrease water consumption in their facilities using existing equipment by making several operational changes. Installing flow restrictors on all kitchen sink faucets and not allowing faucets to run during food preparation will save water. Recipes should be followed for the correct amount of water to decrease waste and minimize cooking time. Frozen food should be defrosted in the refrigerator instead of under running water. All serviceware washing equipment should be run only with full loads. Serviceware should be scraped, not rinsed, before dish machine operation. Starchy foods such as rice and pasta should not be placed in the garbage disposal because more water is required to flush the starch through the system (18).

\section{Air Quality}

Clean air is another resource that is essential to the quality of life for all living things. Human impact on air quality has been the subject of much debate in recent years. Issues such as air pollution, depletion of the ozone layer, and global warming all have implications for the food system.

Air pollution is defined as the presence of substances in the air that are at concentration levels interfering with human comfort, health, and safety. The Clean Air Act of 1963, and its subsequent amendments, resulted in the introduction of environmental policies and regulations designed to improve air quality (30). The EPA's Office of Quality Planning develops strategies to control pollutant emissions from a variety of sources, including foodservice operations. Particulates from foodservice equipment such as broilers, fryers, smokers, and grills can generate air pollution. The vents and hoods that direct these particulates to outdoor air are regulated by the EPA. Service vehicles used by foodservice operations also may generate air pollution. The cost to purchase and maintain service vehicles must be included in the cost to transport goods (31).

Refrigeration of perishable food is essential for protecting safety and quality. Chlorofluorocarbons and hydrofluorocarbons are effective coolants for refrigeration and air conditioning systems but contribute to depletion of the earth's ozone layer. The Clean Air Act amendment of 1990 was passed to ensure US compliance with the 1987 Montreal Protocol and the 1992 Copenhagen Amendment (32). The 1987 Montreal Protocol identified chlorofluorocarbons, hydrofluorocarbons (propellants), carbontetrachloride, methylchloroform (industrial solvents), and methylbromide (pesticide) as contributing to ozone depletion. Chlorofluorocarbons have been banned since 2000, and hydrofluorocarbon manufacture will be discontinued in developed countries after 2030. Three common refrigerants used for air conditioning, R-11, R-12, and R-202, will be phased out by 2020 (33). All repairs to refrigeration systems must be performed by a certified person (33). Food and nutrition professionals should consider alternative refrigerants when making equipment purchase decisions. The ADA supports the development of new refrigerants, alternative cleaning agents, and pesticides that are energy efficient and environmentally safe.

Indoor air quality is considered an environmental health risk. This is important because the average person spends about $90 \%$ of the day indoors (33). Smoking bans have been implemented by many facilities and jurisdictions to reduce exposure to secondhand smoke. The EPA has identified primary sources that contribute to indoor air pollution such as cleaning solvents, combustible materials, and building materials and insulation including asbestos, furniture made from certain types of pressed wood, central heating and cooling systems, damp carpets, pesticides, and radon. The American Society of Heating, Refrigerating, and Air Conditioning Engineers recommends levels of carbon dioxide, humidity, temperature, and particulates for optimal comfort and safety (34). Maintenance may be as important as facility design for maintaining indoor air quality (35). The EPA has developed HealthySEAT, a software tool that helps schools identify indoor air health and safety issues before they become problems $(36,37)$. Poor indoor air quality has been associated with Sick Building Syndrome, which can increase labor costs caused by absences (38). Food and nutrition professionals should work with their facility engineers and maintenance departments to provide efficient ventilation, climate control, and removal of particulates to maintain air quality.

\section{MINIMIZING AND MANAGING WASTE Municipal Solid Waste}

Municipal solid waste is defined as any solid, semisolid, or liquid substance that is a byproduct of residential, institutional, commercial, or industrial sources. It excludes wastes generated from building construction or demolition, combustion wastes, automotive scraps, and municipal sludge. In 2003, more than 236 million tons of municipal solid waste were produced from residential, business, and institutional sources, which is about $4.5 \mathrm{lbs}$ of waste per person per day (39). The largest categories as a percentage of total municipal solid waste before recycling were: paper, $35.2 \%$; yard waste, $12.1 \%$; food scraps, $11.7 \%$; and plastic, $11.3 \%$ (39). Schools, health care, and commercial operations generate $35 \%$ to $45 \%$ of the total municipal solid waste in the United States.

The EPA has developed a hierarchy of solid waste that promotes environmentally sound strategies for municipal solid waste. Source reduction (including reuse) is the most preferred method, followed by recycling and composting, and, lastly, disposal in combustion facilities and landfills. Currently, $30 \%$ is recovered and recycled or composted, $14 \%$ is burned at 
combustion facilities, and the remaining $56 \%$ is disposed of in landfills (39). Source reduction practices include purchasing products made with recycled content or products with minimal packaging, two-sided copying of paper, and transport packaging reduction. Food waste may be recovered for composting or animal feed. In 2003, food waste accounted for $2.7 \%$ of the total recycled municipal solid waste. A limited amount was composted in approximately 3,227 community composting programs (40).

The EPA has established WasteWise, a free, voluntary program providing technical assistance for source reduction to all organizations. WasteWise is a flexible program that allows partners to design their own waste reduction programs tailored to their needs (41). For example, a yogurt manufacturer in the northeast United States donated 336 tons of yogurt manufacturing byproduct to local farmers to use as animal feed. The company also donated 45 tons of yogurt to food banks and recycled 327 tons of paper, cardboard, and aluminum. A public school participating in WasteWise composted 900 lbs of cafeteria food waste for mulch on building grounds (42).

Food and nutrition professionals can conduct solid waste audits to determine the major components of their facility's waste stream. The solid waste audit methodology developed by Mason and colleagues (18) can be adapted to a variety of foodservice operations. Local conditions such as the availability of recycling outlets will determine the type of solid waste management program implemented to reduce the volume of waste generated through recycling, source reduction, or donations to a local food bank or farm. Opportunities for source reduction will depend on the type of service system, menu, purchasing system, and serviceware $(43,44)$. The University of California-Berkeley Dining Services provides an example of an integrated natural resource management program. They implemented water and energy conservation measures and reduced the quantity of solid and hazardous waste produced in order to meet "green building" criteria established by the US Green Building Council. Solid waste management included vermicomposting of preconsumer waste, re- cycling cans and cardboard, and donating leftover food to local homeless shelters (45). The volume of solid waste generated was reduced by $50 \%$. Waste removal costs are assessed by volume; reductions in the volume generated would decrease disposal costs, and could reduce fossil fuel used for transport to landfills.

\section{Hazardous Materials}

The Resource Conservation and Recovery Act defines hazardous waste as a material that shows ignitability, corrosiveness, reactivity, or toxicity (46). State or local governments also may designate waste as hazardous. Staff often encounter solvents, compounds, and solutions that could cause harm if used improperly or accidentally. Both the Occupational Safety and Health Administration and the Joint Commission require health care facilities to develop an emergency management plan that includes chemical isolation and decontamination (47). The Hazard Communication Standard ("Hazcom" or "employee right to know") requires copies of all Material Safety Data Sheets for potentially harmful substances to be on file in a facility. RDs and DTRs often are responsible for maintaining these files and for educating employees about hazardous substances. The Medical Waste Tracking Act of 1988 provides information about chemicals and other hazardous materials in the workplace (47). ADA supports the development of alternative pesticides and cleaning products that minimize environmental impact and reduce the risk of harmful effects on humans.

\section{SUPPORTING SUSTAINABLE AGRICULTURE AND COMMUNITY FOOD SYSTEMS Agriculture and Food Guidance}

Food and nutrition professionals can educate themselves about agriculture basics and the production methods that help provide ecologically sustainable food choices. Sustainable agriculture, for example, seeks to conserve finite resources, including topsoil, water, and fossil energy (48), recognizing that the environment and natural resources are the foundation of activity in the agricultural economy (49).

Industrial food production, although producing an abundance of relatively inexpensive food, incurs external costs that are paid in part by natural resource depletion and degradation. Loss of topsoil represents the largest of these external costs (50). Each inch of topsoil takes decades to form, but about 1.7 billion tons are lost annually in the United States (51). Excessive tilling, heavy equipment, and livestock overgrazing can damage soil structure. Excessive irrigation, in addition to depleting underground aquifers, can leave behind salts that reduce soil fertility (salinization), eventually leading to desertification or loss of arable land (52). Eroding soil can transport toxic materials such as agrochemicals. Soil particles end up in waterways and reservoirs, damaging aquatic ecosystems and decreasing water storage capacity (50).

Although soil conservation is only one aspect of sustainable food production, organic production methods can result in improved soil fertility. The National Organic Program stipulates that Certified Organic Agricultural Systems must maintain soil fertility by adding organic material (crop residue and animal manure), rather than by using chemical fertilizers (53). In a comparison of organic and conventional farming systems, researchers found that levels of soil organic matter were higher in organic systems. Organic systems also had reduced soil erosion because of the use of crop rotation and cover cropping (54). The nutrient content of our food is directly related to soil quality. A decline in the mineral content of our food crops because of degraded soil fertility has some scientists concerned, although changes in cultivated varieties may be one explanation for the declines observed $(55,56)$.

Within the food system, the major water user is the agricultural sector, which consumes $84 \%$ of freshwater supplies. In addition, agriculture is a significant source of water resource degradation. Pesticides enter surface water and ground water systems and have been detected in drinking water. Fertilizers and livestock waste contribute nitrates, which threaten ecosystems and human health. Livestock waste also can introduce diseasecausing parasites (eg, Cryptosporidium and Giardia) to surface water (50).

As previously stated, the US food 
system is heavily dependent on energy. Dietary protein choices can make a significant difference in the amount of energy we consume. Overall, animal protein production requires 25 kcal for each kilocalorie produced as food. Grain protein production requires only $2.2 \mathrm{kcal}$ per food kilocalorie. The kind of animal protein also makes a difference. For example, for each food calorie produced, broiler chicken production requires $4 \mathrm{kcal}$, turkey requires $10 \mathrm{kcal}$, milk and pork both require $14 \mathrm{kcal}$, eggs require $39 \mathrm{kcal}$, beef $40 \mathrm{kcal}$, and lamb 57 kcal. Energy inputs depend on the livestock feed (ie, grain versus pasture). When livestock are pasture fed, energy costs can be reduced by half (57).

RDs and DTRs can encourage eating that is both healthful and conserving of soil, water, and energy by emphasizing plant sources of protein and foods that have been produced with fewer agricultural inputs. ADA encourages professionals to educate themselves about the benefits and limitations of organic production methods for contributing to sustainable food systems.

Biodiversity, along with soil, water, and energy, is part of the natural resource foundation that sustains our food supply. Genetic diversity is the primary source of variation. It enables producers to choose food plants suited to the specific environments and conditions under which they are cultivated.

The United States is home to natural centers of diversity for sunflowers, blueberries, cranberries and other small fruits, pecans and walnuts, forage crops, grasses, and a variety of medicinal plants. However, we are heavily dependent on other parts of the world for the genetic diversity of our most important food crops and staples (eg, corn, wheat, rice, soybeans) (58).

Many plant genetic resources that are important for future agricultural development and food security are currently threatened. Although environmental degradation and conversion of forests for other uses causes loss of genetic diversity, the most important cause globally is the spread of modern industrial agriculture. This loss occurs when traditional varieties of crops are replaced with new, more genetically uniform varieties. Indige- nous knowledge about these varieties and their cultivation also can be lost (58). Pesticides used in agricultural production negatively affect wildlife populations, some of which are themselves food sources or critical players in food production systems. Examples include fish populations; honeybees and birds, which are pollinators of food plants; and insect predators, which help control populations of pest species (50). Organic and other alternative growing systems contain relatively higher levels of biodiversity (59). Loss of genetic diversity makes food production vulnerable to widespread crop losses caused by pests, disease, pathogens, and environmental changes (58).

\section{Food and nutrition professionals can help protect farmland by supporting policies that maintain a viable agricultural base in their local communities.}

ADA affirms that food biotechnology has many potentially positive applications (60). ADA also encourages professionals to continue educating themselves and providing information to consumers about this new technology. Genetically engineered seeds present some significant contradictions regarding ecological sustainability. Although genetic engineering of food plants may reduce the use of pesticides on certain crops and allow for the use of less toxic pesticides on others $(60,61)$, the use of genetically modified seeds may result in contamination of natural flora, and in some cases, threaten organic and other sustainable farming systems in the United States and developing countries (59).

RDs and DTRs can encourage eating that is mindful of biodiversity, such as increasing dietary variety among and within food groups, and recommending shopping at farmers' markets or local farm stands, where sustainably grown and regionally unique varieties of fruits, vegetables, and animal products are sold. Heirloom varieties, for example, are garden plants that have been passed down through generations. They are not bred for commercial production, but each variety is genetically unique with natural resistance to pests and disease. Heirloom varieties serve as gene banks for commercial producers and can be used to infuse new traits into genetically narrow commercial varieties, helping to ensure sustained production (62).

Future capacity for food production in the United States will depend in part on how we allocate land resources today. According to the most recent National Resources Inventory Report (51), the contiguous 48 states of the United States cover 1.9 billion acres, which includes 405 million acres of rangeland, 117 million acres of pasture, and 368 million acres of cropland. The amount of land we use to grow crops has decreased $12 \%$ since 1982 and $2 \%$ since 1997.

Food choices have a significant effect on the quantity of land needed for food production. In a comparison of environmental impacts of different protein choices, researchers found that meat protein required more land to produce than vegetable protein by a factor ranging from 6 to 17. In addition, meat protein production required approximately 26 times more water than vegetable protein on rainfed lands, and production of vegetable proteins was 2.5 to 50 times more energy efficient than meat production, depending on the intensity of agricultural practices (63). It is important to note that environmental resource conservation associated with plantbased diets is diminished when foodstuffs are transported long distances. For example, local, organically produced meat may have a lower environmental impact than transported produce (63). Livestock grazed on indigenous grasslands (eg, grass-fed beef) is an example of a sustainable agricultural system because external inputs are minimized (64).

According to the 2002 Census of Agriculture, the United States has fewer and larger farms than in 1997 (65). A large percentage of the nation's food output is in the "path of development." The farms in urban-influenced areas account for $86 \%$ of fruit and vegetable production, $63 \%$ of milk, 


\begin{tabular}{|c|c|}
\hline \multicolumn{2}{|c|}{ Actions in Dietetic Practice } \\
\hline Dietary Guidance and Community Nutrition & Food Management \\
\hline $\begin{array}{l}\text { - Encourage dietary variety among and within food groups and } \\
\text { consumption of heirloom varieties. } \\
\text { - Encourage consumption of food produced with fewer } \\
\text { agricultural inputs (eg, certified organic, grass-fed or range-fed } \\
\text { meats, pastured poultry). } \\
\text { - Encourage the consumption of locally produced foods through } \\
\text { farm stands, farmers' markets, food cooperatives, and } \\
\text { community supported farms. } \\
\text { - Work to improve access to locally produced foods. } \\
\text { - Get involved in a buy-local campaign. } \\
\text { - Encourage connections between local producers and local } \\
\text { institutions. } \\
\text { - Encourage consumption of fresh or minimally processed foods. } \\
\text { - Encourage consumption of protein from plant sources. } \\
\text { Encourage economic food purchasing that also reduces } \\
\text { packaging waste. }\end{array}$ & $\begin{array}{l}\text { - Offer a variety of food choices. } \\
\text { - Purchase unique varieties of produce. } \\
\text { - Purchase foods produced with fewer agricultural inputs. } \\
\text { - Purchase foods direct from local growers (ie, farm-to- } \\
\text { - } \text { institution) and reduce reliance on imported foods. } \\
\text { - Conduct an energy audit; track energy use. } \\
\text { - Choose Energy Star and water-conserving appliances. } \\
\text { - Use energy-and water-saving cooking strategies. } \\
\text { - Maintain appliances and cookware well. } \\
\text { - Follow WaterWiser and WasteWise }{ }^{\text {b }} \text { recommendations. } \\
\text { - Choose earth-friendly cleaning and pest-control products. } \\
\text { - Minimize use of garbage disposal by scraping dishes. } \\
\text { - Run dishwasher only when full. } \\
\text { - Defrost foods in the refrigerator, not under running water. } \\
\text { - Consider alternative refrigerants. } \\
\text { - Avoid appliances that release hydrochlorofluorocarbons. } \\
\text { - Conduct a solid waste audit. } \\
\text { - Minimize food waste. } \\
\text { - Recycle cooking oil through a bio-diesel production facility. } \\
\text { - Donate leftovers to emergency food suppliers. } \\
\text { - Donate food scraps for composting or animal feed. } \\
\text { - Recycle glass, metal, plastic, cardboard, etc. } \\
\text { - Purchase recycled materials. } \\
\text { - Maintain ventilation and climate control equipment well. }\end{array}$ \\
\hline \multicolumn{2}{|c|}{ Actions in the Community and at Home } \\
\hline Public Policy and Education & Personal Lifestyle \\
\hline $\begin{array}{l}\text { Educate yourself about: } \\
\text { - local and regional agriculture; } \\
\text { - places to purchase local foods; } \\
\text { - the relationship between biodiversity and food security; } \\
\text { - the importance of soil in food production, nutrition, and food } \\
\text { security; } \\
\text { - local land use issues; } \\
\text { - US energy consumption; } \\
\text { - sources of local drinking water; and } \\
\text { - local sources of air pollution. } \\
\text { Support government programs and policies that: } \\
\text { - conserve genetic resources; } \\
\text { - conserve soil (Conservation Reserve Program); } \\
\text { - protect farmland through zoning, easements, tax reform, sale } \\
\text { of development rights; } \\
\text { - encourage farm-to-school programs and school gardens; } \\
\text { - encourage the development of alternative energy sources; } \\
\text { - protect the quality of freshwater (eg, the Clean Water Act); } \\
\text { - protect air quality (eg, the Clean Air Act); } \\
\text { - encourage waste reduction through reuse and recycling; and } \\
\text { - improve accessibility to clean drinking water in public } \\
\text { institutions. }\end{array}$ & $\begin{array}{l}\text { - Purchase foods produced with fewer agricultural inputs. } \\
\text { - Increase consumption of protein from plant sources. } \\
\text { - Grow or raise your own fruits, vegetables, and animal products. } \\
\text { Try heirloom varieties. } \\
\text { - Compost food scraps, lawn, and garden wastes. } \\
\text { - Support urban gardens and farms. } \\
\text { - Support local growers through farm stands, farmers' markets, } \\
\text { food cooperatives and community supported farms. } \\
\text { - Live close to where you work. } \\
\text { - Reduce reliance on imported foods. } \\
\text { - Walk and bike more. } \\
\text { - Choose fuel-efficient vehicles. } \\
\text { - Follow WaterWise and WasteWise recommendations. } \\
\text { - Use water and energy conserving appliances at home. } \\
\text { - Choose earth-friendly cleaning and pest-control products. } \\
\text { - Turn off water when not in use; repair leaks promptly. } \\
\text { - Reduce unnecessary consumption. } \\
\text { - Minimize food waste. } \\
\text { - Reuse containers when possible. } \\
\text { - Recycle food containers. } \\
\text { - Purchase foods with less packaging. } \\
\text { - Drink filtered tap water vs bottled water. }\end{array}$ \\
\hline
\end{tabular}

Figure 2. Registered dietitian and dietetic technician, registered actions to conserve natural resources and support the ecological sustainability of

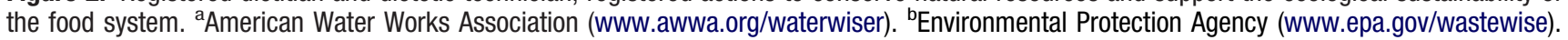




\section{Internet Resources for Natural Resource Conservation and Supporting the Ecological Sustainability of the Food System}

Sustainable Agriculture and Natural Resources

Healthy Land, Healthy People: Building a Better Understanding of Sustainable Food Systems for Food and Nutrition Professionals (available to ADA members only)

ADA Hunger and Environmental Nutrition (HEN) dietetic practice group

HEN Organic Talking Points

National Organic Program

Natural Resource Conservation Service

United Nations Food and Agriculture Organization (FAO)

Local Food and Community Food Systems

World Hunger Year Food Security Learning Center

Ecological Footprint

FoodRoutes

Farm to School

US Department of Agriculture's Farmers' Market

Directory

Food Cooperative Directory

Community-Supported Agriculture

Seed Savers Exchange

Native Seeds/SEARCH (Southwestern Endangered Aridland Resource Clearing House)

\section{Energy}

Energy Information Administration

Energy Star program

Consortium for Energy Efficiency

Pacific Gas and Electric Food Service Guide

\section{Solid Waste}

Environmental Protection Agency (EPA)—Wastes

BioCycle (composting and recycling)

Solid Waste Systems (Spokane, WA)

Recycled disposable serviceware

Water

EPA WaterSense

Energy and Water Efficiency

\section{Air Quality}

EPA Indoor Air Quality

\section{Foodservice Facilities}

Food Management

US Green Building Council

Green facility maintenance products

Ecologically safe products

Earth Friendly Products
www.eatright.org/ada/files/Sustainable_Primer.pdf

www.hendpg.com

www.hendpg.com/files/HEN_Talking_Points_

About_Organic_Farming060606.pdf

www.ams.usda.gov/nop/indexIE.htm

www.nrcs.usda.gov

www.fao.org

www.worldhungeryear.org/fslc

www.myfootprint.org

www.foodroutes.org

www.farmtoschool.org

www.ams.usda.gov/farmersmarkets/map.htm

www.coopdirectory.org

www.nal.usda.gov/afsic/csa

www.seedsavers.org

www.nativeseeds.org/v2/default.php

www.eia.doe.gov

www.energystar.gov

www.cee1.org

www.pge.com/biz/rebates/express_efficiency/

useful_info/food_service_guide.html

www.epa.gov/epaoswer/osw/index.htm

www.jgpress.com/biocycle.htm

www.solidwaste.org

www.treecycle.com

www.epa.gov/owm/water-efficiency

www.watergy.org

www.epa.gov/iaq

www.food-management.com

www.usgbc.org

www.ecosafetyproducts.com

www.ecosafeproducts.com

www.ecos.com 
$39 \%$ of meat, and $35 \%$ of grain (66). Despite high development pressure on some of America's most productive farmland, there are several strategies that communities can use to protect farmland and keep it in production. Examples of such strategies include zoning, creating agricultural districts, purchasing or transferring development rights, tax reform, and conservation easements (67). Food and nutrition professionals can help protect farmland by supporting policies that maintain a viable agricultural base in their local communities.

\section{Community Food Systems}

Feenstra (68) describes community food systems as collaborative efforts to build more locally based, self-reliant food economies in which sustainable food production, processing, distribution, and consumption are integrated to enhance the economic, environmental, and social health of a particular place. This position is particularly concerned with how community food system building can serve as a strategy to improve or maintain the environmental health of localities. For example, food may travel 1,400 to 2,400 miles before reaching its final destination (69). Buy-local campaigns are raising consumer awareness about the importance of protecting the agricultural landscape by supporting local farm businesses with food purchases (70).

There are several ways that food and nutrition professionals can participate in community food system building (71). An initial strategy would be to gain familiarity with regional agriculture and what is available seasonally, and then explore the venues where locally grown produce and animal products are sold directly to consumers. These venues include farm stands, farmers' markets, and community-supported farms. Community-supported agriculture is a relatively new concept in the United States in which members of the community purchase farm shares ahead of the growing season and then receive a weekly box or basket of harvest produce (72). A second step is facilitating connections among local producers and the foodservice departments of local schools, hospitals, prisons, and other workplaces. Farm-toschool and farm-to-college programs are becoming more popular, and there are several current models showing success $(73,74)$. In health care, Kaiser Permanente has shown innovative leadership by opening organic farmers' markets in its hospitals and medical office buildings throughout the nation as part of a comprehensive food policy (75).

\begin{tabular}{l}
\hline ADA members are \\
encouraged to \\
evaluate their \\
personal and \\
professional \\
practices and take \\
action to more \\
effectively conserve \\
natural resources \\
and support the \\
ecological \\
sustainability of the \\
food system.
\end{tabular}

Food and nutrition professionals who provide food guidance can help clients make ecologically sustainable food choices by equipping themselves with knowledge of local food sources. By procuring food from local sources, food managers can help create stable markets for local producers, offer fresh local food to customers, and help educate community members about the sources of their food. Sourcing locally is a way to protect the local agricultural landscape, indirectly conserve water and energy, and avoid increases in food costs as energy costs increase.

\section{Global Perspective}

Global food security now and in the future ultimately is dependent on how we manage and conserve the natural resources that are the foundation of our food system. Nations are more interconnected and interdependent now than ever before. The United States is heavily dependent on other nations for the genetic diversity of commercially grown food plants. While our farmland base shrinks, ever-growing populations of other na- tions continue to rely on staple foods produced in the United States. Residents of the United States consume almost five times more energy than the average global citizen, and up to 17 times more energy than residents of many developing nations (76). As India and China continue to develop and gain wealth, there will be increased competition for finite resources. Air and water are dynamic natural resources that flow freely within and among nations. All nations will suffer the effects of freshwater depletion and global warming. RDs and DTRs, among others, need to keep in mind that our actions have global consequences. Conserving and protecting resources in many small ways will contribute to global food system sustainability now and in the future.

\section{APPLICATIONS FOR FOOD AND NUTRITION PROFESSIONALS}

ADA members are encouraged to evaluate their personal and professional practices and take action to more effectively conserve natural resources and support the ecological sustainability of the food system. Food and nutrition professionals' knowledge of the complex issues associated with environmental concerns should be increased through participation in continuing education activities and research. Knowledgeable members should be proactive in implementing programs in their workplaces, homes, and communities to conserve natural resources and protect the environment. They also should participate in the legislative process within their states and communities. Figure 2 provides a summary of actions that conserve natural resources and support the ecological sustainability of the food system.

\section{References}

1. Sobal J, Khan LK, Bisogni C. A conceptual model of the food and nutrition system. Soc Sci Med. 1998;47:853-863.

2. Herremans IM, Reid RE. Developing awareness of the sustainability concept. J Env Educ. 2002;34:16-20.

3. Brundtland GH. Our Common Future. New York, NY: Oxford University Press; 1987:43.

4. Dahlberg KA. Regenerative food systems: Broadening the scope and agenda of sustainability. In: Allen P, ed. Food for the Future: Conditions and Contradictions of Sustain- 
ability. New York, NY: John Wiley; 1993:75102.

5. Herrin M, Gussow JD. Designing a sustainable regional diet. J Nutr Educ. 1989;21: 270-275.

6. Energy Information Administration. Annual Energy Outlook 2006. Report \#DOE/EIA0383. Available at: http://www.eia.doe.gov./ oiaf/aeo/index.html. Accessed May 4, 2006.

7. Consortium for Energy Efficiency. High-efficiency specifications for CEE's Commercial Kitchens Initiative. 2006. Available at: http: www.cee1.org/com/com-kit/com-kit-main.php3. Accessed June 27, 2006.

8. Energy Information Administration. Annual Energy Review 2004. Report \#DOE/EIA0384. Available at: http://www.eia.doe.gov/ emeu/aer/overview.html. Accessed May 4, 2006.

9. Multi-Sponsor Surveys, Inc. The 2005 Gallup Study of Home Meal Replacements. Princeton, NJ: Multi-Sponsor Surveys, Inc; 2005. Available at: http://www.multisponsor. com/cat/Food $\% 20$ Beverage $\% 20$ and $\% 20$ Nutrition/Food\%20Preparation\%20and $\% 20$ Eating\%20Habits/Food\%20and\%20Beverage $\% 20$ Issues $\% 20$ and $\% 20$ Trends $\% 20$ Report $\%$ 2025038.pdf. Accessed April 2, 2007.

10. Rosenquist G, McNeil M, Iyer M, Meyers S, McMahon J. Energy Efficiency Standards for Residential and Commercial Equipment: Additional Opportunities. Environmental Energy Technologies Division, Lawrence Berkeley National Laboratory. Berkeley, CA: US Department of Energy; 2004.

11. Seelye K. Thinking "green" means thinking sustainably. Food Management. 2006;41:3234.

12. Energy Star. Making the business case for energy management in healthcare. 2006. Available at: http://www.energystar.gov/ index.cfm?c=healthcare.business_case. Accessed July 28, 2006

13. Arizona Public Service. Energy efficient commercial kitchen. 2006. Available at: http://www.aps.com/images/pdf/cooking.pdf. Accessed June 27, 2006.

14. Bendall D. High speed cooking [Well Equipped]. Food Management. April 2005: 78-80.

15. Bendall D. Playing it cool [Well Equipped]. Food Management. March 2006:78-82.

16. Scriven C, Stevens J. Food Equipment Facts: A Handbook for the Foodservice Industry. Weimar, TX: Chips Books; 1999:390.

17. Hayter SJ, Torcellini PA, Eastment M, Judkoff R. Using the Whole-Building Design Approach to Incorporate Daylighting into a Retail Space. Department of Energy: National Renewable Energy Laboratory; 2002.

18. Mason D, Shanklin CW, Hee Wie S, Wolfe K. Environmental Issues Impacting Foodservice and Lodging Operations. Manhattan, KS: Kansas State University; 1999.

19. Thimmakka's Resources for Environmental Education. Restaurant/FoodService Industry-Energy Conservation Standards. Available at: http://www.thimmakka.org/Activities/ Energy_guidelines. Accessed May 7, 2006.

20. Hackes BL, Shanklin CW. Factors other than environmental issues influence resource allocation decisions of school foodservice directors. J Am Diet Assoc. 1999; 99:944-949.

21. Environmental Protection Agency. How we use water in these United States. 1995. Available at: http://www.epa.gov/ow/you/ chap1.html. Accessed April 19, 2006.
22. American Dietetic Association. Position of the American Dietetic Association: Food and water safety. J Am Diet Assoc. 2003;103: 1203-1218.

23. Environmental Protection Agency. Introducing WAVE-Water Alliances for Voluntary Efficiency: Hotel water management for the $21^{\text {st }}$ century. 1994. Available at: http://www. yosemite.epa.gov/water/owrccatalog.nsf/ EPAtitle/NT00006C0E?OpenDocument. Accessed June 25, 2006.

24. American Water Works Association. WaterWiser. 2006. Available at: http://www.awwa org/waterwiser. Accessed June 25, 2006.

25. Environmental Protection Agency. WaterSense program announced. 2006. Available at: http://www.epa.gov/watersensenews.htm\% 23admin. Accessed June 25, 2006.

26. Federal Energy Management Program. Domestic Water Conservation Technologies. Federal Technical Alert OSTI 15002033. Golden, CO: National Renewable Energy Laboratory; 2002.

27. Bendall D. Clean and efficient [Well Equipped]. Food Management. February $2005 ; 80-82$.

28. Hiller CC, Miller J, Dinse DR. Hot Water Use in a High School Cafeteria. ASHRAE Transactions. Symposia 2004. Vol 110, issue 2, pp 655-663.

29. Shea EJ. Hands-off success: Touch-free sinks offer time-saving conveniences for operators looking to clean up. Restaurants Institutions. 2005;115:38.

30. Environmental Protection Agency. The Clean Air Act. 2006. Available at: http:// www.epa.gov/air/caa/caa109.text. Accessed May 6, 2006.

31. Environmental Protection Agency. The Clean Air Act Title II Part A vehicle requirements. Sec 207. Compliance by vehicles and engines in actual use. 2006. Available at: http://epa.gov/air/caa/caa207.txt. Accessed June 25, 2006

32. Environmental Protection Agency. Acceptable substitutions in retail food refrigeration. 2006. Available at: http://www.epa.gov/ ozone/smap/refrigerants/lists/foodref.html. Accessed May 6, 2006.

33. Environmental Protection Agency. The in side story: A guide to indoor air quality. EPA document \#402-K-93-007. 2006. Available at: http://www.epa.gov/iaq/pubs/insidest. html\#Intro1. Accessed May 6, 2006.

34. American Society of Heating, Refrigerating and Air Conditioning Engineers. ASHRAE Standard: Addendum to Thermal Environmental Conditions for Human Occupancy. ANSI/ASHRAE 55a-1995. Available at: http://www.ashrae.org/doclib/2003691613 347.pdf. Accessed March 22, 2007.

35. Ramachandran G, Adgate J, Banerjee S, Church TR, Jones D, Fredrickson A, Sexton $\mathrm{K}$. Indoor air quality in two urban elementary schools-Measurements of airborne fungi, carpet allergens, $\mathrm{CO}_{2}$, temperature, and relative humidity. J Occup Health Envrion Hyg. 2005;2:553-566.

36. Environmental Protection Agency. Healthy school environments assessment tool Available at: http://www.epa.gov/schools/ healthyseat. Accessed March 26, 2007.

37. Petronella SA, Thomas R, Stone JA, Goldblum RM, Brooks EG. Clearing the air: A model for investigating indoor air quality in Texas schools. J Environ Health. 2005;67: $35-42$.

38. Seppanen O, Fiske WJ. A model to estimate the cost-effectiveness of improving office work through indoor environmental control. ASHRAE Transactions. 2005;111:663-672.

39. Environmental Protection Agency. Municipal solid waste basic facts. 2006. Available at: http://www.epa.gov/msw/facts.htm. Accessed May 5, 2006.

40. Environmental Protection Agency. MSW generation, recycling, and disposal in the US: Facts and figures. Report \#EPA530-F05-003. 2005. Available at: http://www. epa.gov/osw. Accessed May 5, 2006.

41. Environmental Protection Agency. EPA WasteWise Program Overview. 2006. Available at: http://www.epa.gov/wastewise/about/ overview.htm. Accessed May 5, 2006.

42. Environmental Protection Agency. EPA WasteWise case studies. 2006. Available at: http://www.epa.gov/epaoswer/non-hw/reduce/ wstewise/about.htm. Accessed May 5, 2006.

43. Environmental Protection Agency. Managing food scraps as animal feed. EPA530-F96-037. 1996. Available at: http://www.epa. gov/oswer/non-hw.htm. Accessed April 17, 2006.

44. Environmental Protection Agency. Donating surplus food to the needy. EPA530-F-96-038. 1996. Available at: http://www.epa.gov/oswer/ non-hw.htm. Accessed April 17, 2006.

45. Lawn J. Going green. Food Management. 2005;40:28-34

46. Electronic Code of Federal Regulations. 40 CFR Part 261 Subpart C and Subpart D. Identification and listing of hazardous waste. 2005. Available at: http://ecfr.gpoaccess. gov/cgi/t/text/text-idx?c $=$ ecfr\&tpl\%2Findex. tpl. Accessed June 25, 2006.

47. Joint Commission on Accreditation of Healthcare Organizations. In: Hospital Accreditation Standards: Management of the Environment of Care. Oakbrook Terrace, IL: Joint Commission Resources; 2006:279-310.

48. Gussow JD, Clancy KL. Dietary guidelines for sustainability. $J$ Nutr Educ. 1986;18:1-5.

49. Madden JP, Chaplowe SG, For All Generations: Making World Agriculture More Sustainable. Glendale, CA: World Sustainable Agriculture Association; 1997:3-37.

50. Tegtmeier RM, Duffy MD. External costs of agricultural production in the United States. Int J Agricultural Sustainability. 2004;2:1-20

51. Natural Resources Conservation Service, US Department of Agriculture. National Resources Inventory, 2003 Annual NRI released May 2006. Available at: http://www. nrcs.usda.gov/TECHNICAL/land/nri03/ SoilErosion-mrb.pdf. Accessed June 9, 2006.

52. Horrigan L, Lawrence RS, Walker P. How sustainable agriculture can address the environmental and human health harms of industrial agriculture. Environ Health Pers. 2002;110:445-456.

53. US Department of Agriculture, Agriculture Marketing Service. The National Organic Program. 2006. Available at: http://www. ams.usda.gov/nop/NOP/standards/FullText. pdf. Accessed June 9, 2006.

54. Pimentel D, Hepperly P, Hanson J, Douds D, Seidel R. Environmental, energetic, and economic comparisons of organic and conventional farming systems. BioScience. 2005;55: 573-582

55. Mayer A-M. Historical changes in the mineral content of fruits and vegetables. $\mathrm{Br}$ Food J. 1997;99:207-211.

56. Davis DR, Epp MD, Riordan HD. Changes in USDA food composition data for 43 garden 
crops, 1950 to 1999. J Am Coll Nutr. 2004; 23:669-682.

57. Pimental D, Pimental M. Sustainability of meat-based and plant-based diets and the environment. Am J Clin Nutr. 2003; 78(suppl):660S-663S.

58. Food and Agriculture Organization of the United Nations. Report on the State of the World's Plant Genetic Resources for Food and Agriculture. Food and Agriculture Organization Plant Production and Protection Division, Rome. 1996. Available at: http:// www.fao.org/ag/cgrfa/PGR.htm. Accessed May 15, 2006

59. Garcia MA, Altieri MA. Transgenic crops: Implications for biodiversity and sustainable agriculture. Bull Sci Tech Soc. 2005;25: 335-353.

60. American Dietetic Association. Position of the American Dietetic Association: Agriculture and food biotechnology. J Am Diet Assoc. 2006;106:285-293.

61. Kuiper H. Biotechnology, the environment, and sustainability. Nutr Rev. 2003;61:S105S109.

62. Seed Savers Exchange. What are Heirlooms? Available at: http://www.seedsavers. org/savingheirlooms.asp. Accessed January $22,2007$.

63. Reijinders L, Soret S. Quantification of the environmental impact of different dietary protein choices. Am J Clin Nutr. 2003; 78(suppl):664S-668S.

64. Heitschmidt RK, Short RE, Grings EE. Ecosystems, sustainability and animal agriculture. J Anim Sci. 1996;74:1395-1405.

65. US Department of Agriculture, National Agricultural Statistics Service. Census of Agriculture 2002. Available at: http://www.nass usda.gov/Census_of_Agriculture/index.asp. Accessed June 9, 2006.

66. American Farmland Trust. Farming on the Edge: Sprawling Development Threatens America's Best Farmland. Washington, DC: American Farmland Trust; 2002. Available at: http://www.farmlandinfo.org/documents/ 29393/Farming_on_the_Edge_2002.pdf. Accessed October 18, 2006.

67. Daniels T, Bowers D. Holding Our Ground: Protecting America's Farms and Farmland. Washington, DC: Island Press; 2001:105234-A.

68. Feenstra G. Creating space for community food systems: Lessons from the field. Agric Hum Values. 2002;19:99-106.

69. Pirog R, Van Pelt T, Enshayan K, Cook E. Food, fuel, and freeways: An Iowa perspective on how far food travels, fuel usage, and greenhouse gas emissions. Leopold Center for Sustainable Agriculture. 2001. Available at: http://www.leopold.iastate.edu/pubs/staff/ ppp/food_mil.pdf. Accessed January 18, 2007.
70. Food Routes Network. Where does your food come from? 2003. Available at: http://www. foodroutes.org/whycare.jsp/. Accessed June 9, 2006.

71. McCullum C, Desjardins E, Kraak VI, Ladipo P, Costello H. Evidence-based strategies to build community food security. $J \mathrm{Am}$ Diet Assoc. 2005;105:278-283.

72. World Hunger Year. Food Security Learning Center. Community Supported Agriculture. Available at: http://www.worldhungeryear. org/fslc/. Accessed August 14, 2006.

73. Buzalka M. Conference focuses on local food sourcing. Food Management [serial online]. September 2005;34-38. Available at: http:// www.allbusiness.com/management/1128246-1. html. Accessed July 28, 2006.

74. Lefebvre J. A new focus on sustainability. Food Management [serial online]. April 2005:14-16. Available at: http://www.foodmanagement.com. Accessed July 28, 2006.

75. Kaiser Permanente. Kaiser Permanente's comprehensive approach to the obesity epidemic: Bringing expertise and resources to bear at every level. 2006. Available at: http:// www.calwic.org/docs/kaiserbroch_feb06.pdf. Accessed August 14, 2006.

76. World Bank. World Development Indicators 2006. Available at: http://devdata.worldbank. org/wdi2006/contents/index2.htm/. Accessed August 14, 2006

ADA position adopted by the House of Delegates on October 18, 1992, and reaffirmed on September 15, 1995; September 12, 1999; and June 30, 2005. This position will be in effect until December 31, 2010. The ADA authorizes republication of the position, in its entirety, provided full and proper credit is given. Requests to use portions of this position must be directed to ADA Headquarters at 800/877-1600, ext 4835, or ppapers@eatright.org.

Authors: Alison H. Harmon, PhD, RD (Montana State University, Bozeman, MT); Bonnie L. Gerald, PhD, DTR (Louisiana Tech University, Ruston, LA).

Reviewers: Carolyn Bednar, PhD, RD (Texas Woman's University, Denton, TX); Sharon Denny, MS, RD (ADA Knowledge Center, Chicago, IL); Dietitians in Business and Communications dietetic practice group (Linda Schuessler, MS, RD, Fiserv, Inc, Brookfield, WI); Hunger and Environmental Nutrition dietetic practice group (Helen E. Costello, MS, RD, Nutrition Crossroads, Concord, NH); Esther Myers, PhD, RD, FADA (ADA Scientific Affairs, Chicago, IL); Almeda Williams, RD (VAMC, Madison, WI).

Association Positions Committee Workgroup: Debe Nagy-Nero, MS, RD (chair); Helen Lane, PhD, RD; Carol Shanklin, PhD, RD (content advisor). 